\title{
Microbial and Physicochemical Qualities of River Owena Water: An Important Source of Domestic Water in Owena Metropolis
}

\author{
Ayo O. $\mathrm{E}^{1}$, Arotupin D. $\mathrm{J}^{2}$ \\ ${ }^{1}$ Department of Biological Sciences, Joseph Ayo Babalola University Ikeji-Arakeji, Osun State, Nigeria. \\ ${ }^{2}$ Department of Microbiology Federal University of Technology Akure, FUTA.
}

Abstract- Microbial quality, physicochemical parameters and heavy metals determination of water samples from River Owena, Oriade local government area, Owena, Nigeria. For period of dry and wet seasons. The $p H$ of water ranged from 6.72 to $7.52 \pm 0.01$, dissolved oxygen ranged from 5.95 to $7.63 \pm 0.01 \mathrm{mg} / \mathrm{l}$, biological oxygen demand ranged from 3.20 to $11.47 \pm 0.01 \mathrm{mg} / \mathrm{l}$. Other physicochemical parameters measured for the water included alkalinity, turbidity total solids, suspended solids, dissolved solid, total hardness, calcium hardness, magnesium hardness, temperature and conductivity which were of higher values during dry season compared to wet season. The MPN index ranged from 7 tol100 cfu/100 ml, mean concentrations of heavy metals in water such as iron, zinc, manganese, lead, chromium, cadmium, nickel and copper, iron had the highest values of 1.1 to $3.3 \pm 0.01 \mathrm{mg} / \mathrm{l}$ and cadmium had lowest values of 0.01 to $0.06 \pm 0.01 \mathrm{mg} / \mathrm{l}$. A total of ten bacterial species were isolated from River Owena water, which included Escherichia coli, Enterobacter aerogenes, Klebsiella pneumoniae, Staphylococcus aureus, S. epidermidis, Salmonella enteritidis, Micrococcus luteus, Pseudomonas aeruginosa, Proteus vulgaris and Shigella sonnei. A total of eight fungal species were isolated from water of River Owena, which included Aspergillus niger, A. flavus, A. fumigatus, Cladosporium herbarum, Mucor mucedo, M. plumbeus, Fusarium oxysporum and Rhizopus oryzae. The total bacterial count of the water ranged from $2.2 \times 10^{3}$ to $2.25 x$ $10^{3} \pm 0.01 \mathrm{cfu} / \mathrm{ml}$. The total fungal count of the water ranged from $6 \times 10^{3}$ to $1.22 \times 10^{3} \pm 0.01 \mathrm{sfu} / \mathrm{ml}$. However, the quality of the water from this river did not conform to the drinking standard of world health organization (1984) hence poor due to the presence of some pathogenic microorganisms and heavy metals which are of public health significance, but it could be improved upon with appropriate treatment.

Keywords - Microbial, Physicochemical, Heavy metals, Water, Wet and Dry season, Drinking, Health.

\section{INTRODUCTION}

The current concern with regards to environmental quality is partly focused on water because of its importance in maintaining the human health and health of the ecosystem. Freshwater reservoirs play an important role in the livelihood of human populations. They are used as a source of domestic water supply, irrigation, fishery development, hydropower generation and flood control (Kitur, 2009). Additional benefits of the reservoirs are tourist attraction and opening up of new areas for development (Kitur, 2009). According to Junk (2002) and Dudgeon (2006), freshwater ecosystems are vulnerable to human impacts, hence they are likely to be influenced by reservoir catchment activities. This is because terrestrial ecosystems have linkages with aquatic ecosystems (UNEP, 2000). Contamination of aquatic ecosystems with a wide range of pollutants has become a matter of concern over the past few decades (Dirilgen, 2001; Vutukuru, 2005).

FAO (1992) noted that the contamination of water supplies from both natural and anthropogenic sources has impacted on the health and economic status of populations. Human activities cause pollutants such as heavy metals, pesticides and herbicides to enter aquatic ecosystems. Thus, heavy metal pollution is growing at an alarming rate and has become an important worldwide problem (Malik et al., 2010). Increase in population, urbanization, industrialization and agricultural practices as well as lack of environmental regulations have further aggravated the situation (Gupta et al., 2009).

Heavy metals cannot be degraded, but they are deposited, assimilated or incorporated in water, sediments and aquatic biota causing heavy metal pollution in water bodies (Linnik and Zubenko, 2000; Malik et al., 2010). Heavy metals in water can originate both from natural sources, industrial, agricultural and domestic activities in the drainage basin of a water system. As the metal levels in many aquatic ecosystems increase due to anthropogenic activities, they 
raise the concern on metal bioaccumulation through the food chain and related human health hazards (Wright and Welbourn, 2002; Indrajith et al., 2008; Agah et al., 2009).

Raw influent includes household waste liquid from toilets, baths, showers, kitchens, sinks, and so on and so forth that is disposed off via sewers. In many areas, sewage also includes liquid waste from industry and commerce. As rainfall runs over the surface of roofs and the ground, it may pick up various contaminants including soil particles and other sediment, heavy metals, organic compounds animal waste and oil and grease. These contaminants eventually get into the water bodies where they negatively impacts their influence. Since all natural waterways contain bacteria and nutrients, almost any waste compounds introduced into such waterways will initiate biochemical reactions (Gupta et al., 2009). The measurement of dissolved oxygen (DO) can be used to indicate the degree of pollution by organic matter, the destruction of organic substances and the level of self-purification of the water. Its determination is also used in the measurement of biochemical oxygen demand (BOD) (Eniola, 2005; Okonko et al., 2008). From a physical point of view, the suspended solids can lead to the development of sludge deposits and anaerobic conditions when discharged into the receiving environment (Maiti 2004). Chemically, wastewater is composed of organic and inorganic compounds as well as various gases. Organic components may consist of carbohydrates, proteins, fats and greases, surfactants, oils, pesticides, phenols and so on and so forth (Tchobanoglous et al. 2003., Maiti, 2004). Drinking water treatment efforts can become weighed down when water resources are heavily polluted by wastewater microorganism species.

Water is of great importance to all living organisms and it is essential to life. It is one of the most demanded of all urban and rural amenities and it is indispensable for human's activities. The importance of River Owena in Ifedore Local Government, Ondo State, and Oriade local government area of Osun state to Owena town and local native populace of some communities near the river in term of access to domestic water and small scale farming around the river inspired the research. Therefore, this work focused on the microbial and physicochemical qualities of River Owena water with the aim of ascertaining its qualities.

\section{MATERIALS AND METHODS}

The study area

River Owena is located about four kilometers from Joseph Ayobabalola University Ikeji Arakeji along Ilesha-Akure express way in Oriade local government area of Osun State, Nigeria on latitude N 7.403135 and longitude E 5.014589. It is a fresh water and free-flowing during raining season but slow-moving at the onset of dry season. Figure 1 showed the study area and point of samples collection

Study design

The analysis cover a period of six months, from July 2015 to January 2016 covering wet and dry season, water samples were collected at four sampling points (two each at both side of the bridge) once a month. The human activities around the river and the sampling points were evaluated and noted on monthly basis.

Sample collection

Water samples were collected during wet and dry season from four sampling points. Sterile bottles of $500 \mathrm{ml}$ were used for sample collection. All containers were rinsed at least three times with water that is to be analyzed. Samples for microbial analysis were collected aseptically, labeled and stored in ice packed plastic coolers and transported to the laboratory where analysis was done within 24 hours of collection (Dubey and Maheshwari, 2004). 


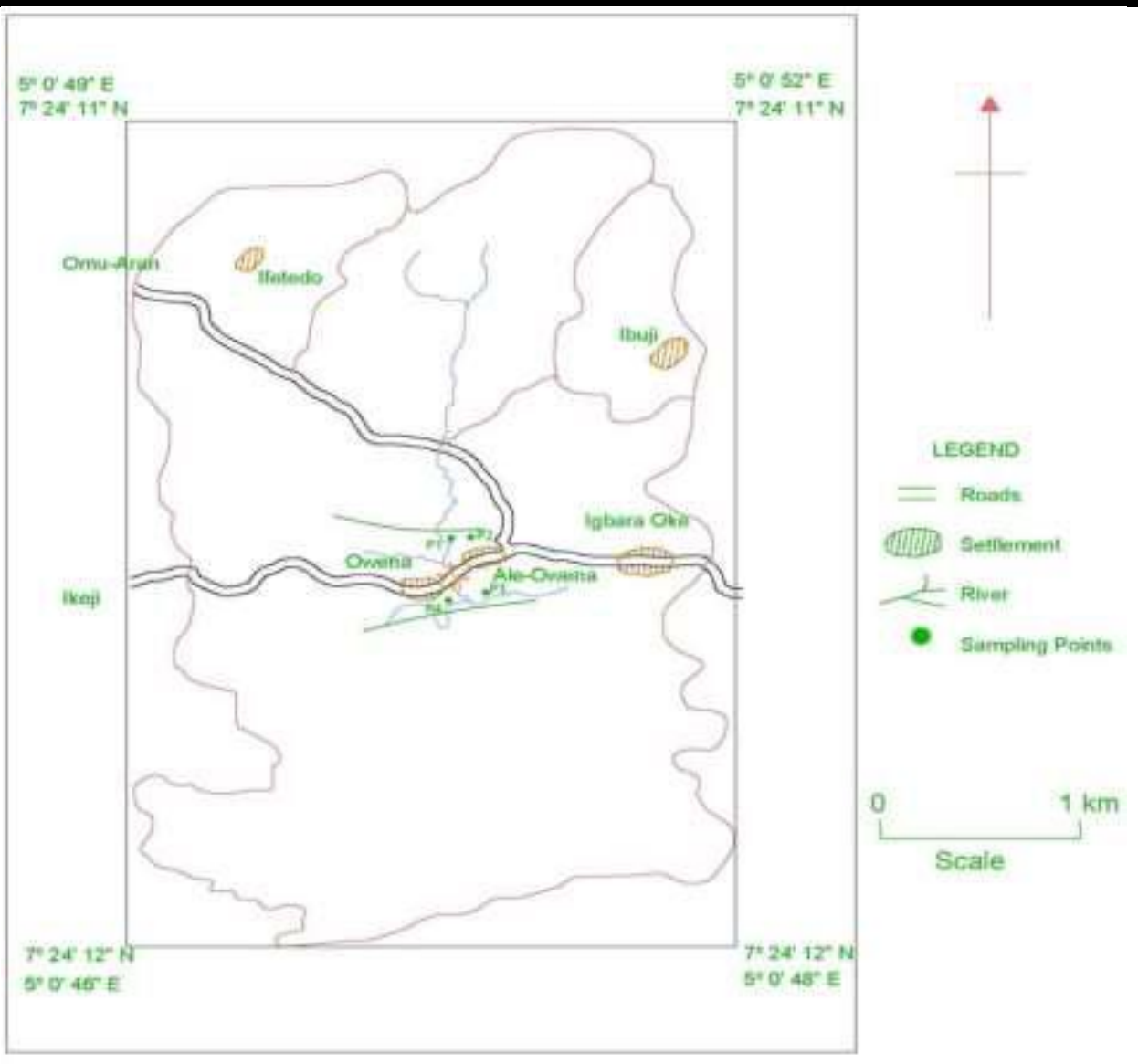

Fig.1: Map of River Owena sampling sites

Test for water coliform

This was carried out in three stages which were presumptive test, confirmatory test and completed test, using standard method of (APHA, 2002)

Isolation of bacteria from water

Pour plate method was used to isolate bacteria from water samples and bacterial count determined using standard method of APHA, (2002); Dubey and Maheshwari, (2004). Purification, characterization and identification of bacterial isolates

Pure cultures were obtained by streaking different and distinct colonies onto sterile nutrient agar plates and incubated for growth. Characterization and identification of bacterial isolates were based on the colonial morphology and biochemical tests carried out on pure culture of the isolates (Buchanan and Gibbons, 1974; Fawole and Oso, 2001; Dubey and Maheshwari, 2004; Garrity et al., 2004).

Isolation of fungi from water samples

Pour plate method was used to isolate fungi from water samples, one milliliter of the water from the different points were serial diluted to obtain $10^{-1}$ to $10^{-9}$ dilutions and pour plate method was done. The plates were incubated at $28 \pm 2^{\circ} \mathrm{C}$ for $48-72$ hours and fungal counts was determined (Olayemi, 1990; APHA, 2002; Dubey and Maheshwari, 2004).

Purification, characterization and identification of fungal isolates

Pure cultures were obtained, by subculturing the grown colonies and culture of the fungal isolates were examined macroscopically and microscopically using lacto-phenol cotton blue to determine their colonial and morphological characteristics respectively. The isolates were identified according to the keys of Onions et al. (1981), Alabi (1994), Fawole and Oso (2001) and Dubey and Maheshwari (2004). Determination of physicochemical characteristics of water samples

Physicochemical characteristics of the water samples from four sampling points were determined once a month. The physicochemical characteristics such as $\mathrm{pH}$, turbidity, total solids, suspended solids, dissolved solids, colour, total hardness, alkalinity, temperature, conductivity, dissolved oxygen, biological oxygen demand, nitrate, phosphate and 
chloride, were determined using standard method of (Anon, 2002), trace and heavy metals determination was carried out following the method of Ravera et al. (2003) and Aiyesanmi (2006).

\section{RESULTS AND DISCUSSION}

The physicochemical characteristics of River Owena water during wet and dry season are illustrated in table 1 and 2 . The temperature obtained from the water samples from River Owena ranged from 25.98 to $27.11 \pm 0.01{ }^{\circ} \mathrm{C}$, the colour values ranged from 31.00 to $34.10 \pm 0.01$ (Pt/Co unit), turbidity values ranged from 7.98 to $8.78 \pm 0.01$ NTU, conductivity values ranged from 111.03 to $112.37 \pm 0.01$ $\mu \mathrm{S} / \mathrm{cm}$, total dissolved solid values ranged from 54.37 to $56.76 \pm 0.01 \mathrm{mg} / \mathrm{l}$, total suspended solid values ranged from 2.03 to $3.12 \pm 0.01 \mathrm{mg} / \mathrm{l}$, total solid values ranged from 57.49 to $58.79 \pm 0.01 \mathrm{mg} / \mathrm{l}$ during wet season (Table 1 ). Also, the $\mathrm{pH}$ of water samples from River Owena ranges from 6.72 to $6.86 \pm 0.01$, which was slightly neutral, the total alkalinity values ranged from 59.33 to $66.33 \pm 0.01 \mathrm{mg} / 1 \mathrm{CaCo}_{3}$, total hardiness values ranged from 66.00 to $71.00 \pm 0.01 \mathrm{mg} / \mathrm{l}$ $\mathrm{CaCo}_{3}$, calcium hardiness values ranged from 14.53 to $16.93 \pm 0.01 \mathrm{mg} / \mathrm{l}$, magnesium hardiness had values ranging from 6.52 to $8.21 \pm 0.01 \mathrm{mg} / 1$, sodium hardiness values ranging from 11.33 to $18.66 \pm 0.01 \mathrm{mg} / \mathrm{l}$, potassium values ranged from 15.00 to $2.33 \pm 0.01 \mathrm{mg} / \mathrm{l}$, dissolved oxygen (DO) ranged from 6.73 to $7.63 \pm 0.01 \mathrm{mg} / \mathrm{l}$, biochemical oxygen demand (BOD) values ranged from 10.70 to $11.47 \pm 0.01 \mathrm{mg} / \mathrm{l}$. chemical oxygen demand (COD) values ranged from 18.50 to $19.80 \mathrm{mg} / \mathrm{l}$, chloride values ranged from 18.17 to $20.00 \pm 0.01 \mathrm{mg} / \mathrm{l}$, nitrate values of ranged from 1.03 to $1.30 \pm 0.01 \mathrm{mg} / \mathrm{l}$, and phosphate values ranged from 0.08 to $0.17 \pm 0.01 \mathrm{mg} / \mathrm{l}$ during wet season (Table 1 ).

However the temperature obtained from the water samples from River Owena ranged from 31.90 to $32.20 \pm 0.01{ }^{\circ} \mathrm{C}$, this was higher compare to that of wet season which may be due to the high intensity of the sun during dry season. Temperature is an important factor in the survival of microorganisms in surface water as it affects the metabolic activities, water activity of microbial cells, Ogunnusi and Olanipekun (2010) and Ogbonna et al. (2010). Colour values ranged from 25.67 to $29.33 \pm 0.01$ ( $\mathrm{Pt} \mathrm{Co}$ unit) turbidity values ranged from 5.88 to $7.83 \pm 0.01$ NTU, High turbidity levels were obtained in all the samples with the lowest turbidity value obtained during dry season, while in December which was harmattan period and no rain had the lowest level hence, its clear nature. Wet season had higher values and the water colour of the river turns brownish. Only sample point three in dry season had a value that fall within the permissible limit of WHO (1984), the rest samples for all the months showed pronounced deviations from WHO standard of 5.0 NTU. The values in all the samples during the period of wet season were high when run-off from land enters the river which is similar to the results obtained by Akpata and Ekundayo (1983). Conductivity values ranged from 138.90 to $148.10 \pm 0.01$ $\mu \mathrm{S} / \mathrm{cm}$, total dissolved solid values ranged from 57.42 to $70.76 \pm 0.01 \mathrm{mg} / \mathrm{l}$, total suspended solid values ranged from 1.34 to $2.01 \pm 0.01 \mathrm{mg} / \mathrm{l}$, and total solid values ranged from 58.76 to $78.28 \pm 0.01 \mathrm{mg} / \mathrm{l}$ during dry season (Table 2 ). In addition, the $\mathrm{pH}$ of water samples from River Owena ranged from 6.94 to $7.52 \pm 0.01$. Sample point four had the highest value of $7.52 \pm 0.01$ which was slightly alkaline and sample point one had the lowest of $6.94 \pm 0.01$ which was neutral slightly, the $\mathrm{pH}$ of water samples from River Owena was observed to be higher during dry season compare to wet season which was similar to that obtained by Ogunnusi and Olanipekun (2010) in a similar work in Oyo town with their own range of 6.39 to 8.95 . This was also obtained by Olayemi (1994) and Ogbonna et al. (2010) of various water samples, variations in the $\mathrm{pH}$ is related to seasonal changes of rain and dryness. Total alkalinity values ranged from 98.23 to $107.20 \pm 0.01 \mathrm{mg} / 1 \mathrm{CaCo}_{3}$, total hardiness values ranged from 75.20 to $90.67 \pm 0.01 \mathrm{mg} / 1 \mathrm{CaCo}_{3}$, calcium hardiness values ranged from 14.98 to $17.96 \pm 0.01 \mathrm{mg} / \mathrm{l}$, magnesium hardiness values ranged from 8.39 to $11.72 \pm 0.01 \mathrm{mg} / \mathrm{l}$, sodium hardiness values ranged from 13.77 to $18.67 \pm 0.01 \mathrm{mg} / \mathrm{l}$, potassium values ranged from 20.43 to $24.97 \pm 0.01 \mathrm{mg} / \mathrm{l}$, these values were higher during dry season than wet season and were within the permissible limit of NSDQW (2007) which is $150 \mathrm{mg} / \mathrm{l}$, similar to that obtained by Akpata and Ekundayo (1983), Ogunnusi and Olanipekun (2010) and Ogbonna et al. (2010). Dissolved oxygen (DO) ranged from 5.95 to $6.23 \pm 0.01 \mathrm{mg} / \mathrm{l}$ biochemical oxygen demand (BOD) values ranged from 3.20 to $5.00 \pm 0.01 \mathrm{mg} / \mathrm{l}$. Chemical oxygen demand (COD) values ranged from 13.57 to $14.40 \pm 0.01 \mathrm{mg} / \mathrm{l}$, chloride values ranged from 24.90 to $34.03 \pm 0.01$, nitrate values of ranged from 0.21 to $0.39 \pm 0.01 \mathrm{mg} / \mathrm{l}$, and phosphate values ranged from 0.18 to $0.23 \pm 0.01 \mathrm{mg} / \mathrm{l}$ during dry season (Table 2), Chloride values of the water was higher during dry season than wet season, the presence of chloride ions in the water bodies is an indication that chloride ion is higher in this environment, at elevated levels. Chloride can inhibit plant growth, slow reproduction and reduce diversity of aquatic life, this is similar to results obtained by Odeyemi et al., (2009). Nitrate values of the water had a lower range during dry season than wet season. The presence of Proteus 
specie as part of the isolates in this study could have a contributory factor to the levels of nitrate obtained. Since Proteus specie live in the soil and water, and organic detritus consists of large amounts of protein and nucleic acids from dead organisms and nitrogenous animal wastes such as urea and uric acid. This is similar to results obtained by Odeyemi et al., (2009). Phosphate values were higher during dry season compare to wet, this is similar to results obtained by Odeyemi et al., (2009).

Table.1: Physicochemical properties of River Owena water (wet season)

\begin{tabular}{|c|c|c|c|c|}
\hline Parameters & P1 & $\mathbf{P 2}$ & $\mathbf{P 3}$ & $\mathbf{P 4}$ \\
\hline Temp $\left({ }^{\circ} \mathrm{C}\right)$ & $27.11 \pm 0.01^{\mathrm{c}}$ & $25.98 \pm 0.01^{\mathrm{a}}$ & $27.10 \pm 0.01^{\mathrm{c}}$ & $26.50 \pm 0.01^{\mathrm{b}}$ \\
\hline Colour (Pt/Co unit) & $34.09 \pm 0.01^{\mathrm{d}}$ & $32.46 \pm 0.01^{\mathrm{b}}$ & $31.00 \pm 0.01^{\mathrm{a}}$ & $33.27 \pm 0.01^{\mathrm{c}}$ \\
\hline Turbidity ( NTU) & $8.51 \pm 0.01^{\mathrm{b}}$ & $7.95 \pm 0.01^{\mathrm{a}}$ & $8.78 \pm 0.01^{\mathrm{d}}$ & $8.61 \pm 0.01^{\mathrm{c}}$ \\
\hline Cond. $(\mu \mathrm{S} / \mathrm{cm})$ & $111.01 \pm 0.00^{\mathrm{c}}$ & $108.73 \pm 0.01^{\mathrm{a}}$ & $109.01 \pm 0.00^{\mathrm{b}}$ & $112.38 \pm 0.01^{\mathrm{c}}$ \\
\hline TD.Solid (mg/L) & $54.87 \pm 0.01^{\mathrm{a}}$ & $54.37 \pm 0.01^{\mathrm{c}}$ & $54.49 \pm 0.01^{\mathrm{d}}$ & $56.76 \pm 0.01^{\mathrm{b}}$ \\
\hline TS.Solid (mg/L) & $2.92 \pm 0.60^{\mathrm{b}}$ & $3.12 \pm 0.00^{\mathrm{d}}$ & $3.02 \pm 0.01^{\mathrm{c}}$ & $2.03 \pm 0.60^{\mathrm{a}}$ \\
\hline T.Solid (mg/L) & $57.79 \pm 0.01^{\mathrm{b}}$ & $57.49 \pm 0.01^{\mathrm{a}}$ & $57.51 \pm 0.01^{\mathrm{a}}$ & $58.79 \pm 0.01^{\mathrm{c}}$ \\
\hline $\mathrm{pH}$ & $6.85 \pm 0.01^{\mathrm{b}}$ & $6.88 \pm 0.01^{\mathrm{c}}$ & $6.88 \pm 0.01^{\mathrm{c}}$ & $6.71 \pm 0.01^{\mathrm{a}}$ \\
\hline P.Alkal. (mg/L $\left.\mathrm{CaCo}_{3}\right)$ & 00.00 & 00.00 & 00.00 & 00.00 \\
\hline T.Alkal. (mg/L $\left.\mathrm{CaCo}_{3}\right)$ & $66.32 \pm 0.01^{\mathrm{d}}$ & $65.32 \pm 0.01^{\mathrm{c}}$ & $59.32 \pm 0.01^{\mathrm{a}}$ & $60.01 \pm 0.01^{\mathrm{b}}$ \\
\hline T.Hard. (mg/L $\left.\mathrm{CaCo}_{3}\right)$ & $66.67 \pm 0.01^{\mathrm{b}}$ & $68.67 \pm 0.01^{\mathrm{c}}$ & $66.01 \pm 0.01^{\mathrm{a}}$ & $71.02 \pm 0.01^{\mathrm{d}}$ \\
\hline $\mathrm{Ca}^{2+}(\mathrm{mg} / \mathrm{L})$ & $15.12 \pm 0.01^{\mathrm{b}}$ & $14.52 \pm 0.01^{\mathrm{a}}$ & $16.92 \pm 0.01^{\mathrm{c}}$ & $14.41 \pm 0.01^{\mathrm{a}}$ \\
\hline $\mathrm{Mg}^{2+}(\mathrm{mg} / \mathrm{L})$ & $7.33 \pm 0.01^{b}$ & $6.52 \pm 0.01^{\mathrm{a}}$ & $7.35 \pm 0.01^{\mathrm{c}}$ & $8.21 \pm 0.01^{\mathrm{d}}$ \\
\hline $\mathrm{Na}^{+}(\mathrm{mg} / \mathrm{L})$ & $18.66 \pm 0.01^{\mathrm{a}}$ & $11.33 \pm 0.01^{\mathrm{c}}$ & $18.66 \pm 0.01^{\mathrm{a}}$ & $16.32 \pm 0.01^{\mathrm{b}}$ \\
\hline $\mathrm{K}^{+} \quad(\mathrm{mg} / \mathrm{L})$ & $16.32 \pm 0.01^{\mathrm{a}}$ & $15.01 \pm 0.01^{\mathrm{b}}$ & $20.32 \pm 0.01^{\mathrm{d}}$ & $16.66 \pm 0.01^{\mathrm{c}}$ \\
\hline DO $(\mathrm{mg} / \mathrm{L})$ & $7.62 \pm 0.01^{\mathrm{a}}$ & $7.62 \pm 0.01^{\mathrm{a}}$ & $6.72 \pm 0.01^{\mathrm{c}}$ & $7.26 \pm 0.01^{\mathrm{b}}$ \\
\hline $\mathrm{BOD}_{5}(\mathrm{mg} / \mathrm{L})$ & $10.72 \pm 0.01^{\mathrm{a}}$ & $10.86 \pm 0.01^{\mathrm{b}}$ & $10.72 \pm 0.01^{\mathrm{a}}$ & $11.46 \pm 0.01^{\mathrm{c}}$ \\
\hline $\mathrm{COD}(\mathrm{mg} / \mathrm{L})$ & $18.51 \pm 0.01^{\mathrm{a}}$ & $19.81 \pm 0.01^{\mathrm{b}}$ & $19.61 \pm 0.01^{\mathrm{c}}$ & $19.02 \pm 0.01^{\mathrm{d}}$ \\
\hline $\mathrm{Cl}^{-}(\mathrm{mg} / \mathrm{L})$ & $20.01 \pm 0.01^{\mathrm{b}}$ & $18.66 \pm 0.01^{\mathrm{b}}$ & $16.66 \pm 0.01^{\mathrm{a}}$ & $19.32 \pm 0.01^{\mathrm{b}}$ \\
\hline $\mathrm{NO}_{3}^{-}(\mathrm{mg} / \mathrm{L})$ & $1.31 \pm 0.01^{\mathrm{d}}$ & $1.02 \pm 0.01^{\mathrm{a}}$ & $1.04 \pm 0.01^{\mathrm{b}}$ & $1.21 \pm 0.01^{\mathrm{c}}$ \\
\hline $\mathrm{PO}_{4}{ }^{3-}(\mathrm{mg} / \mathrm{L})$ & $0.06 \pm 0.01^{\mathrm{a}}$ & $0.16 \pm 0.01^{\mathrm{c}}$ & $0.15 \pm 0.01^{\mathrm{c}}$ & $0.12 \pm 0.01^{\mathrm{b}}$ \\
\hline
\end{tabular}

*Data are presented as Mean \pm S.E $(n=3)$. Values in the same row followed by the same superscript letters are not significantly different using Duncan's multiple range test at $\mathrm{p}<0.0$

Table.2: Physicochemical properties of River Owena water (dry season)

\begin{tabular}{|c|c|c|c|c|}
\hline Parameters & $\mathbf{P 1}$ & $\mathbf{P 2}$ & $\mathbf{P 3}$ & P4 \\
\hline Temp $\left({ }^{\circ} \mathrm{C}\right)$ & $32.11 \pm 0.01^{\mathrm{c}}$ & $31.97 \pm 0.01^{b}$ & $31.91 \pm 0.01^{\mathrm{a}}$ & $32.21 \pm 0.01^{\mathrm{d}}$ \\
\hline Colour (Pt/Co unit) & $29.33 \pm 0.01^{\mathrm{d}}$ & $26.01 \pm 0.01^{\mathrm{b}}$ & $25.68 \pm 0.01^{\mathrm{a}}$ & $27.05 \pm 0.01^{\mathrm{c}}$ \\
\hline Turbidity ( NTU) & $7.82 \pm 0.01^{\mathrm{d}}$ & $6.36 \pm 0.01^{\mathrm{b}}$ & $5.87 \pm 0.01^{\mathrm{a}}$ & $7.01 \pm 0.01^{\mathrm{c}}$ \\
\hline Cond. $(\mu \mathrm{S} / \mathrm{cm})$ & $138.91 \pm 0.01^{\mathrm{a}}$ & $139.02 \pm 0.01^{\mathrm{a}}$ & $141.65 \pm 0.01^{\mathrm{a}}$ & $145.77 \pm 0.01^{b}$ \\
\hline TD.Solid (mg/L) & $68.92 \pm 0.01^{\mathrm{c}}$ & $57.42 \pm 0.01^{\mathrm{a}}$ & $60.62 \pm 0.01^{\mathrm{b}}$ & $70.76 \pm 0.01^{\mathrm{d}}$ \\
\hline TS.Solid (mg/L) & $1.97 \pm 0.01^{\mathrm{c}}$ & $1.34 \pm 0.01^{\mathrm{a}}$ & $1.52 \pm 0.01^{\mathrm{b}}$ & $2.01 \pm 0.01^{\mathrm{d}}$ \\
\hline T.Solid (mg/L) & $70.89 \pm 0.01^{\mathrm{c}}$ & $58.76 \pm 0.01^{\mathrm{a}}$ & $62.14 \pm 0.01^{b}$ & $78.28 \pm 0.01^{\mathrm{d}}$ \\
\hline $\mathrm{pH}$ & $6.94 \pm 0.01^{\mathrm{a}}$ & $7.22 \pm 0.01^{\mathrm{c}}$ & $7.12 \pm 0.01^{b}$ & $7.52 \pm 0.01^{\mathrm{d}}$ \\
\hline P.Alkal. (mg/L $\left.\mathrm{CaCO}_{3}\right)$ & 00.00 & 00.00 & 00.00 & 00.00 \\
\hline T.Alkal. (mg/L CaCo 3 ) & $98.22 \pm 0.01^{\mathrm{a}}$ & $100.55 \pm 0.01^{b}$ & $111.33 \pm 0.01^{\mathrm{d}}$ & $107.21 \pm 0.01^{\mathrm{c}}$ \\
\hline T.Hard. (mg/L $\left.\mathrm{CaCo}_{3}\right)$ & $89.76 \pm 0.01^{\mathrm{c}}$ & $88.52 \pm 0.01^{b}$ & $75.21 \pm 0.01^{\mathrm{a}}$ & $90.66 \pm 0.01^{\mathrm{d}}$ \\
\hline $\mathrm{Ca}^{2+}(\mathrm{mg} / \mathrm{L})$ & $14.98 \pm 0.01^{\mathrm{a}}$ & $17.96 \pm 0.01^{b}$ & $17.01 \pm 0.01^{\mathrm{b}}$ & $14.97 \pm 0.01^{\mathrm{a}}$ \\
\hline $\mathrm{Mg}^{2+}(\mathrm{mg} / \mathrm{L})$ & $11.72 \pm 0.01^{\mathrm{d}}$ & $9.57 \pm 0.01^{\mathrm{b}}$ & $8.38 \pm 0.01^{\mathrm{a}}$ & $10.32 \pm 0.01^{\mathrm{c}}$ \\
\hline $\mathrm{Na}^{+}(\mathrm{mg} / \mathrm{L})$ & $17.01 \pm 0.01^{\mathrm{c}}$ & $13.76 \pm 0.01^{\mathrm{a}}$ & $18.66 \pm 0.01^{\mathrm{d}}$ & $14.62 \pm 0.01^{\mathrm{b}}$ \\
\hline $\mathrm{K}^{+}(\mathrm{mg} / \mathrm{L})$ & $21.96 \pm 0.01^{b}$ & $22.12 \pm 0.01^{\mathrm{c}}$ & $24.96 \pm 0.01^{\mathrm{d}}$ & $20.42 \pm 0.01^{\mathrm{a}}$ \\
\hline
\end{tabular}


$\mathrm{DO}(\mathrm{mg} / \mathrm{L})$

$\mathrm{BOD}_{5}(\mathrm{mg} / \mathrm{L})$

$\mathrm{COD}(\mathrm{mg} / \mathrm{L})$

$\mathrm{Cl}^{-}(\mathrm{mg} / \mathrm{L})$

$\mathrm{NO}_{3}{ }^{-}(\mathrm{mg} / \mathrm{L})$

$\mathrm{PO}_{4}{ }^{3-}(\mathrm{mg} / \mathrm{L})$

$7.28 \pm 0.01^{\mathrm{d}}$

$4.42 \pm 0.01^{\mathrm{c}}$

$13.81 \pm 0.01^{\mathrm{b}}$

$34.02 \pm 0.01^{\mathrm{d}}$

$0.35 \pm 0.01^{b}$

$0.15 \pm 0.01^{\mathrm{a}}$

\section{$5.94 \pm 0.01^{\mathrm{a}}$}

$3.91 \pm 0.01^{\mathrm{b}}$

$14.41 \pm 0.01^{\mathrm{c}}$

$25.93 \pm 0.01^{\mathrm{b}}$

$0.34 \pm 0.01^{\mathrm{b}}$

$0.21 \pm 0.01^{\mathrm{b}}$
$5.98 \pm 0.01^{\mathrm{b}}$

$3.21 \pm 0.01^{\mathrm{a}}$

$13.81 \pm 0.01^{\mathrm{b}}$

$25.97 \pm 0.01^{\mathrm{c}}$

$0.38 \pm 0.01^{\mathrm{d}}$

$0.16 \pm 0.01^{\mathrm{a}}$

*Data are presented as Mean \pm S.E $(n=3)$. Values in the same row followed by the same superscript letters are not significantly different using Duncan's multiple range test at $\mathrm{p}<0.05$

Water purity assessment of River Owena (dry and wet season)

Most Probable Number index (MPN) of water samples from River Owena in July 2015 to Jan. 2016 illustrated that wet season had the highest MPN of $1100 \mathrm{cfu} / 100 \mathrm{ml}$ in August and September, point three and point four, lowest value of $73 \mathrm{cfu} / 100 \mathrm{ml}$ in September, point three (Figure 3). The water sample had highest MPN of $150 \mathrm{cfu} / 100 \mathrm{ml}$ in Oct., point one and lowest value of $7 \mathrm{cfu} / 100 \mathrm{ml}$ in November, point two during dry season (Figure 4). The result indicated that the river was contaminated with feaces, thus contain pathogens that can cause gastroenteritis, hence is neither potable nor fit for domestic use and recreational activities. The higher microbial counts obtained during the wet season was due to increased nutrients and aeration which enhanced decomposition of organic matter, hence increase in bacterial populations as supported by Gareth (1973) and Olayemi (1990).

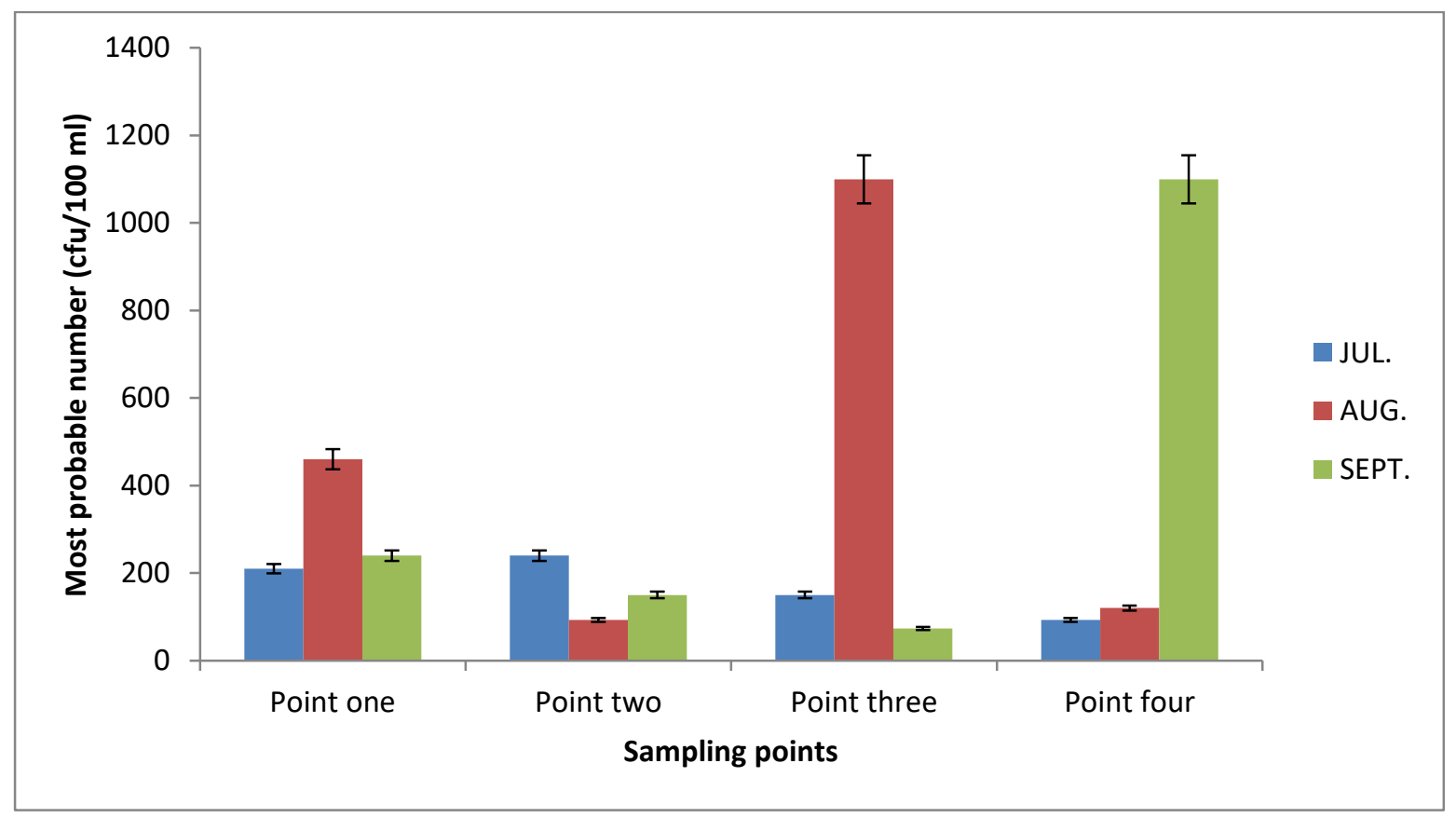

Fig.3: Wet season most probable number index values of River Owena water 


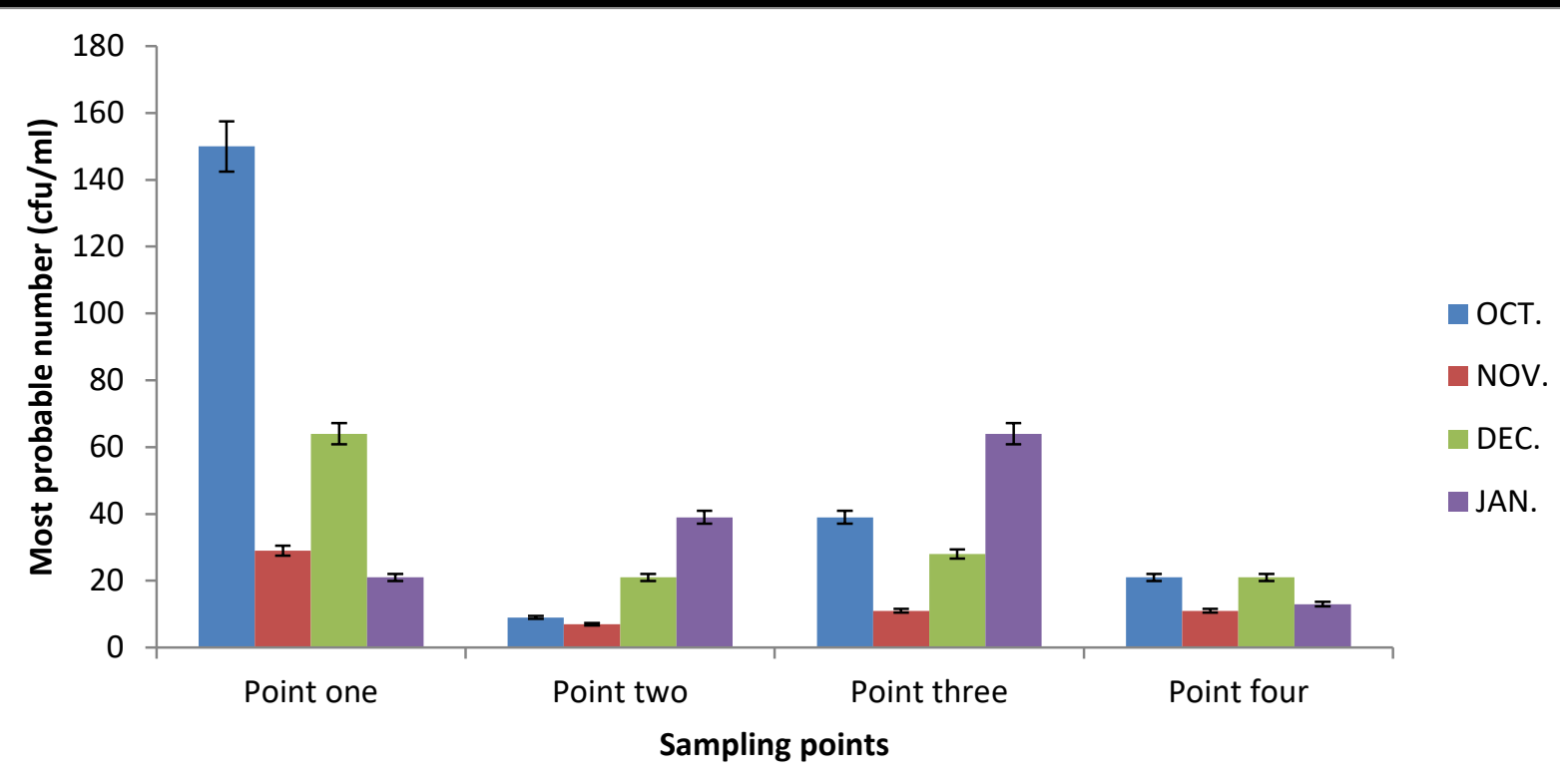

Fig.4: Dry season most probable number index values of River Owena water

Heavy metals of River Owena water (dry and wet season) The mean concentrations of heavy metals $(\mathrm{mg} / \mathrm{l})$ of water samples determined during the wet season showed that iron has the highest values ranged from 1.1 to $1.21 \pm 0.01 \mathrm{mg} / \mathrm{l}$, while cadmium had the least values of 0.01 to $0.02 \pm 0.01$ $\mathrm{mg} / \mathrm{l}$ (Figure 5). During dry season iron had the highest values ranged from 2.42 to $3.30 \pm 0.01 \mathrm{mg} / \mathrm{l}$, while cadmium had the least values of 0.02 to $0.06 \pm 0.01 \mathrm{mg} / \mathrm{l}$ (Figure 6). The mean concentrations of heavy metals $(\mathrm{mg} / \mathrm{l})$ of water samples was found to be higher during dry season compare to wet season. This result is similar to the one obtained by Dosumu et al. (2003) and Adefemi and Awokunmi (2010).

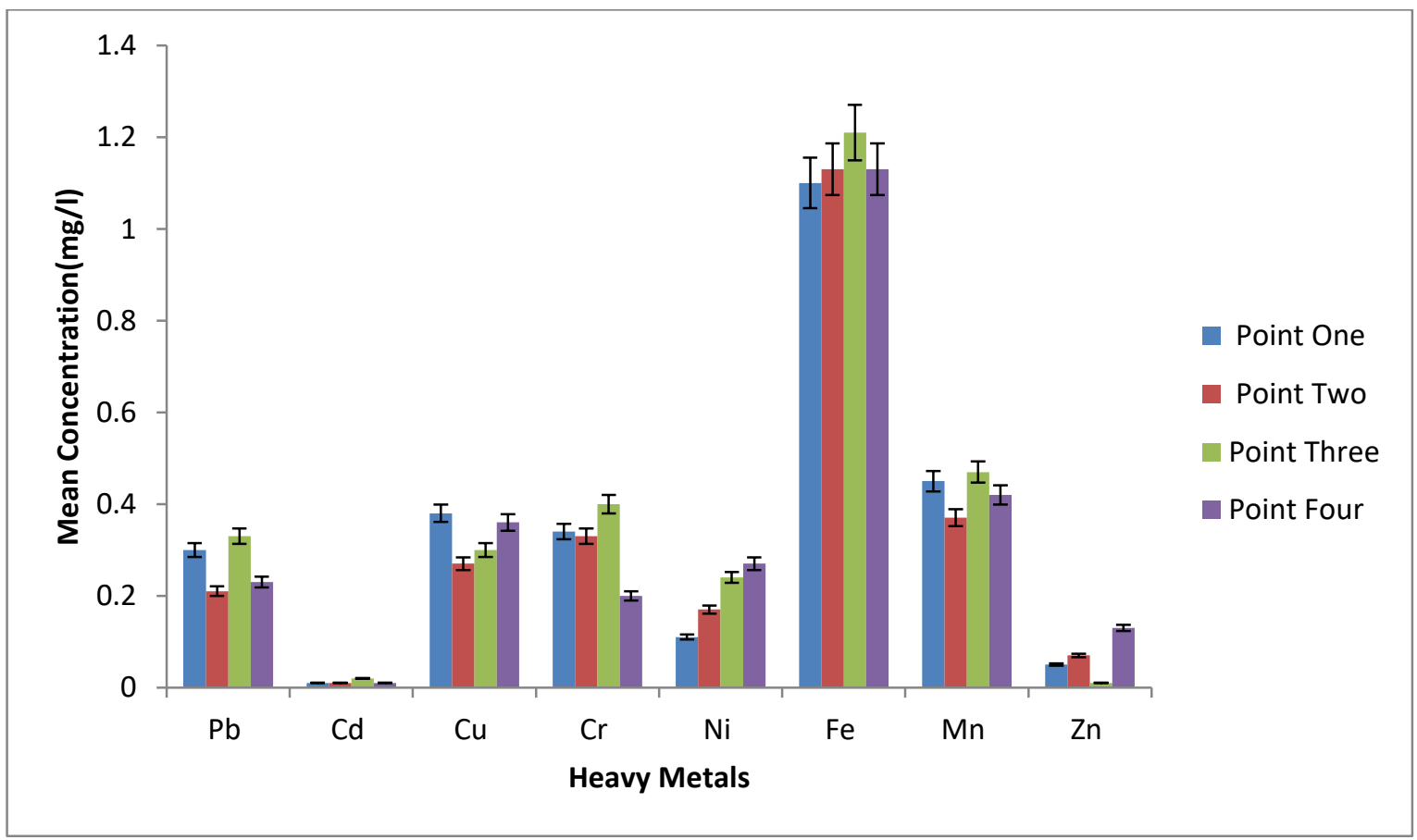

Fig.5: Wet season mean concentration of heavy metals of River Owena water 


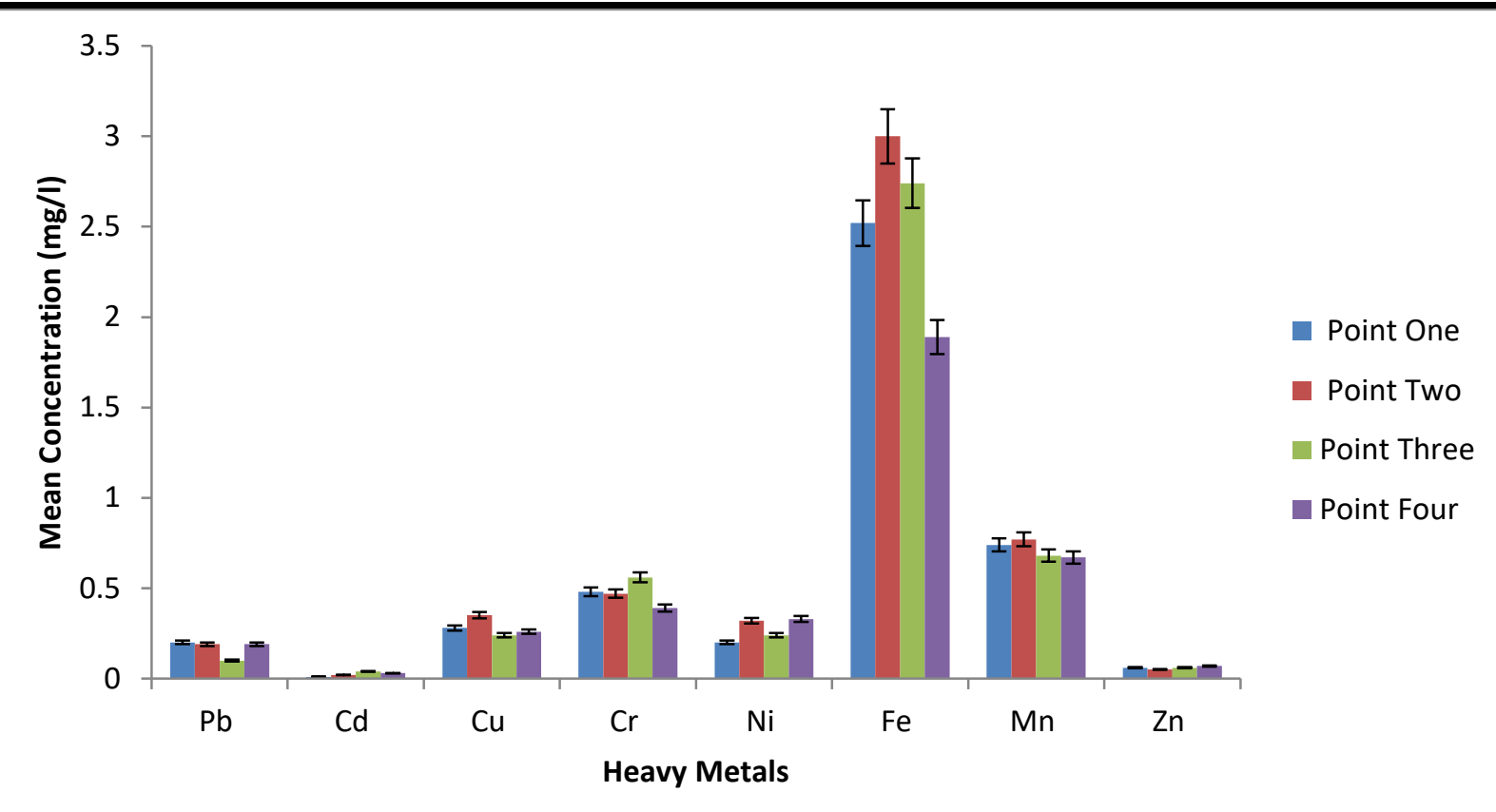

Fig.6: Dry season mean concentration of heavy metals of River Owena water

The total bacterial counts $(\mathrm{cfu} / \mathrm{ml})$ of River Owena water The total bacterial counts for the four samples points of water determined from July 2015 to Jan. 2016 covering (wet and dry seasons) ranged from $2.2 \times 10^{3}$ to $2.25 \mathrm{x}$ $10^{3} \pm 0.01 \mathrm{cfu} / \mathrm{ml}$ (Table 3 ). The lowest count occurred in sample point four in August, 2015, while the highest count occurred in sample point one in July, 2015. Wet season ranged $2.25 \times 10^{3} \pm 0.01 \mathrm{cfu} / \mathrm{ml}$ in July, 2015 to $2.2 \mathrm{x}$ $10^{3} \pm 0.01 \mathrm{cfu} / \mathrm{ml}$ in August, 2015, dry season ranged $1.42 \mathrm{x}$ $10^{3} \pm 0.01 \mathrm{cfu} / \mathrm{ml}$ in Nov., 2015 to $5.5 \times 10^{3} \pm 0.01 \mathrm{cfu} / \mathrm{ml}$ in Dec., illustrated that wet season had a higher bacterial count compared dry season, the increase in bacterial load during wet season could be due to run-off.

Table.3: Total bacterial counts of River Owena water

$\begin{array}{llll}\text { Months } & \text { Point One } & \text { Point Two Point Three } & \text { Point Four }\end{array}$

\begin{tabular}{lllll}
\hline July.2015 & $2.25 \times 10^{3} \pm 0.01^{\mathrm{d}}$ & $1.23 \times 10^{3} \pm 0.01^{\mathrm{c}}$ & $9.8 \times 10^{3} \pm 0.01^{\mathrm{a}}$ & $1.20 \times 10^{3} \pm 0.01^{\mathrm{b}}$ \\
Aug. 2015 & $3.3 \times 10^{3} \pm 0.01^{\mathrm{b}}$ & $6.0 \times 10^{3} \pm 0.01^{\mathrm{d}}$ & $4.9 \times 10^{3} \pm 0.01^{\mathrm{c}}$ & $2.2 \times 10^{3} \pm 0.01^{\mathrm{a}}$ \\
Sept. 2015 & $1.10 \times 10^{3} \pm 0.01^{\mathrm{b}}$ & $6.6 \times 10^{3} \pm 0.01^{\mathrm{a}}$ & $1.15 \times 10^{3} \pm 0.01^{\mathrm{c}}$ & $1.23 \times 10^{3} \pm 0.01^{\mathrm{d}}$ \\
Oct. 2015 & $4.3 \times 10^{3} \pm 0.01^{\mathrm{a}}$ & $5.2 \times 10^{3} \pm 0.01^{\mathrm{b}}$ & $1.31 \times 10^{3} \pm 0.01^{\mathrm{d}}$ & $8.8 \times 10^{3} \pm 0.01^{\mathrm{c}}$ \\
Nov. 2015 & $1.42 \times 10^{3} \pm 0.01^{\mathrm{d}}$ & $1.21 \times 10^{3} \pm 0.01^{\mathrm{c}}$ & $1.08 \times 10^{3} \pm 0.01^{\mathrm{b}}$ & $7.4 \times 10^{3} \pm 0.01^{\mathrm{a}}$ \\
Dec. 2015 & $6.5 \times 10^{3} \pm 0.01^{\mathrm{a}}$ & $5.5 \times 10^{3} \pm 0.01^{\mathrm{b}}$ & $6.4 \times 10^{3} \pm 0.01^{\mathrm{c}}$ & $7.7 \times 10^{3} \pm 0.01^{\mathrm{d}}$ \\
Jan. 2016 & $1.17 \times 10^{3} \pm 0.01^{\mathrm{d}}$ & $9.4 \times 10^{3} \pm 0.01^{\mathrm{b}}$ & $7.4 \times 10^{3} \pm 0.01^{\mathrm{a}}$ & $1.01 \times 10^{3} \pm 0.01^{\mathrm{c}}$
\end{tabular}

$*$ Data are presented as Mean \pm S.E $(n=3)$. Values in the same row followed by the same superscript letters are not significantly different using Duncan's multiple range test at $\mathrm{p}<0.05$

Bacterial isolates of River Owena water

A total of ten bacterial species were isolated from River Owena water samples. The bacteria included Enterobacter aerogenes, Proteus vulgaris, Escherichia coli, Staphylococcus epidermidis, S. aureus, Pseudomonas aeruginosa, Micrococcus luteus, Shigella sonnei, Klebsiella pneumoniae and Salmonella enteritidis. The frequency of occurrence of each isolate is shown in (Table 4). Both Escherichia coli and Enterobacter aerogenes had highest frequency of occurrence of $20.1 \%$, while Micrococcus luteus had the lowest of $1.8 \%$ and Shigella sonnei, Salmonella enteritidis had $4.3 \%$ frequency of occurrence 
for bacterial isolates. this is similar to the work of Ekpo et al. (2010). Some of the isolates found in River Owena also occurred in findings of other researchers of freshwater in

Table.4: Bacterial frequency distribution of River Owena water

\begin{tabular}{lc}
\hline Isolates & \% Frequency of Occurrence \\
\hline Enterobacter aerogenes & 20.1 \\
Proteus vulgaris & 8.7 \\
Escherichia coli & 20.1 \\
Staphylococcus epidermidis & 12.2 \\
S. aureus & 11.1 \\
Pseudomonas aeruginosa & 8.7 \\
Micrococcus luteus & 1.8 \\
Klebsiella pneumoniae & 8.7 \\
Shigella sonnei & 4.3 \\
Salmonella enteritiditis & 4.3 \\
\end{tabular}

Values represents means \pm Standard error of means.

Fungal count ( $\mathrm{sfu} / \mathrm{ml}$ ) of River Owena water

Total fungal counts for the four samples points of water determined from July 2015 to Jan. 2016 covering (wet and dry seasons) ranged from $6 \times 10^{3}$ to $1.22 \times 10^{3} \pm 0.01 \mathrm{sfu} / \mathrm{ml}$ (Table 5). The lowest count occurred in sample point one in Jan., 2016, while the highest count occurred in sample point different locations in Nigeria which include that of Ogunnusi and Olanipekun (2010) and Ajayi (2010).

Table.5: Total fungal counts of River Owena water

\begin{tabular}{ccccc}
\hline \multicolumn{1}{c}{ Months } & \multicolumn{1}{c}{ Point One } & \multicolumn{1}{c}{ Point Two } & \multicolumn{1}{c}{ Point Three } & \multicolumn{1}{c}{ Point Four } \\
\hline July 2015 & $8 \times 10^{3} \pm 0.01^{\mathrm{a}}$ & $9 \times 10^{3} \pm 0.01^{\mathrm{b}}$ & $1.3 \times 10^{3} \pm 0.01^{\mathrm{c}}$ & $2.9 \times 10^{3} \pm 0.01^{\mathrm{d}}$ \\
Aug. 2015 & $9 \times 10^{3} \pm 0.01^{\mathrm{b}}$ & $1.7 \times 10^{3} \pm 0.01^{\mathrm{a}}$ & $7 \times 10^{3} \pm 0.01^{\mathrm{a}}$ & $1.3 \times 10^{3} \pm 0.01^{\mathrm{c}}$ \\
Sept. 2015 & $1.22 \times 10^{3} \pm 0.01^{\mathrm{c}}$ & $1.05 \times 10^{3} \pm 0.01^{\mathrm{b}}$ & $1.03 \times 10^{3} \pm 0.01^{\mathrm{a}}$ & $1.11 \times 10^{3} \pm 0.01^{\mathrm{b}}$ \\
Oct. 2015 & $2.2 \times 10^{3} \pm 0.01^{\mathrm{c}}$ & $2.5 \times 10^{3} \pm 0.01^{\mathrm{d}}$ & $8 \times 10^{3} \pm 0.01^{\mathrm{a}}$ & $1.0 \times 10^{3} \pm 0.01^{\mathrm{b}}$ \\
Nov. 2015 & $8.3 \times 10^{3} \pm 0.01^{\mathrm{d}}$ & $2.1 \times 10^{3} \pm 0.01^{\mathrm{b}}$ & $6.2 \times 10^{3} \pm 0.01^{\mathrm{c}}$ & $1.5 \times 10^{3} \pm 0.01^{\mathrm{a}}$ \\
Dec. 2015 & $5.3 \times 10^{3} \pm 0.01^{\mathrm{b}}$ & $5.1 \times 10^{3} \pm 0.01^{\mathrm{d}}$ & $4.9 \times 10^{3} \pm 0.01^{\mathrm{c}}$ & $4.2 \times 10^{3} \pm 0.01^{\mathrm{a}}$ \\
Jan.. 2016 & $6 \times 10^{3} \pm 0.01^{\mathrm{a}}$ & $9 \times 10^{3} \pm 0.01^{\mathrm{b}}$ & $2.1 \times 10^{3} \pm 0.01^{\mathrm{c}}$ & $9 \times 10^{3} \pm 0.01^{\mathrm{b}}$ \\
\hline
\end{tabular}

*Data are presented as Mean \pm S.E $(n=3)$. Values in the same row followed by the same superscript letters are not significantly different using Duncan's multiple range test at $\mathrm{p}<0.05$

Fungal isolates of River Owena water

A total of eight fungal species isolated from River Owena water were Aspergillus niger, A. flavus, A. fumigatus, Mucor plumbeus, M. mucedo, Cladosporium herbarum, Fusarium oxysporum and Rhizopus oryzae. The frequency of occurrence of each isolate in (Table 6). Aspergillus niger had the highest occurrence with $21 \%$ frequency of two in Sept., 2015. Wet season ranged $7 \times 10^{3} \pm 0.01 \mathrm{sfu} / \mathrm{ml}$ in Aug., 2015 to $1.22 \times 10^{3} \pm 0.01 \mathrm{sfu} / \mathrm{ml}$ in Sept., 2015. Dry season ranged $6 \times 10^{3} \pm 0.01 \mathrm{sfu} / \mathrm{ml}$ in Jan., 2016 to $8.3 \mathrm{x}$ $10^{3} \pm 0.01 \mathrm{sfu} / \mathrm{ml}$ in Nov. Total fungal counts of the four samples points of water determined illustrated that wet season had higher count compared to dry season. 
Table.6: Fungal frequency distribution of River Owena water

\begin{tabular}{lc} 
Isolates & \% Frequency of Occurrence \\
\hline Aspergillus niger & 21.0 \\
Mucor plumbeus & 15.0 \\
A. flavus & 12.5 \\
Cladosporium herbarum & 9.5 \\
Rhizopus oryzae & 10.3 \\
M. mucedo & 10.3 \\
Fusarium oxysporum & 7.9 \\
A. fumigatus & 13.5 \\
& Total 100 \\
\hline
\end{tabular}

Values represents means \pm Standard error of means.

Sanitary surveillance

Along the bank of the river are farms with crops such as banana, guinea corn, sugar cane and vegetables (spinach), Human activities at the bank of the river were car wash park, washing of clothes, washing of farm implements and so on and so forth. The river also serves as recreational swimming pool for small children, various types of birds including ducks, pigeons and egrets were seen on the river. There are also well-constructed drainages leading into the water which was recently constructed in 2014. Solid waste dump include both biodegradable and non-biodegradable waste matters. Cow dung and human excreta along the bank of the river and inside the shallow areas of the river are all biodegradable, and these droppings were noticed at sampling points three and four. These activities requires monitoring to reduce the pollution level as observed by Environment Canada, (2010) and Figueras et al., (2000). The distribution pattern of wastes noticed at the sampling points (Table 7).

Table.7: Sanitary surveillance at the bank of River Owena

\begin{tabular}{lcccc}
\hline Type of wastes & Point One & Point Two & Point Three & Point Four \\
\hline Solid & + & - & + & + \\
Waste & & & & \\
Dump & & & & + \\
Cow & - & - & + & + \\
Dump & & & & - \\
Domestic & + & - & + & \\
Waste & & & & \\
Droppings & & &
\end{tabular}

The River Owena water was found to favour the growth of bacteria and fungi, which makes it unsafe for consumption, because of the presence of pathogenic microbes. River Owena water therefore needs treatment prior to use for both domestic and recreational purpose.

\section{REFERENCES}

[1] Adefemi, S. O. and Awokunmi, E. E. (2010). Determination of physicochemical parameters and heavy metals in water samples from Itaogbolu area of
Ondo State, Nigeria. African Journal of Environmental Science and Technology 4(3): 145- 148.

[2] Adegunwa, A. (2003). Microorganisms in Sediments of River Oyun and a Pond pp. 1-14. (B.Sc. Project, Department of Microbiology, University of Ilorin, Ilorin, Nigeria.).

[3] Agah H., Leermakers M., Elskens M., Fatemi S. M.R and Baeyens W (2009) Accumulation of trace metals in the muscles and liver of five fish species from the Persian Gulf. Environ. Monit. Assess. 157: 499-514. 
[4] Aiyesanmi A. F.,(2006) "Baseline Concentration of Heavy Metals in Water Samples from Rivers Within Okitipupa South- east Belt of the Nigerian Bitumen Field," Journal of Chemical Society of Nigeria, Vol. 31,No. 1-2, pp. 30-37.

[5] Ajayi, A.O. (2010). Microbiological study of surface and ground water sources in Akungba-Akoko, Ondo state, Nigeria. Book of Abstract (NSM FUTO 2010). pp. 3.

[6] Akpata, T.V.I. and Ekundayo, J.A. (1978). Faecal Pollution of Lagos. Nigeria Journal of Science 12(182):39-52.

[7] Akpata, T.V.I. and Ekundayo, J.A.(1983). Occurrence and Periodicity of some fungal population in Lagos Lagoon. Transactions of British Mycological Society 80:347-352.

[8] Alabi,R.O. (1994). Some Lower Aquatic Phycomycetes from River Oyun. Centre Point 4(1):114.

[9] APHA.(2002). Standard Methods for the Examination of Water and Wastewater. 20th Edition. American Public Health Association, Washington D.C.

[10] Awolumate, O. (1977). Selected methods for soil and plant analysis. Central Analytical Laboratories. Cocoa Research Institute of Nigeria. pp 58-60.

[11] Carla, W. M. (1997). Fundamentals of Geology. Third Edition. WM. C. Brown Publishers, U.K. pp. 339.

[12] Dosumu, O. O., Salami, N. and Adekola, F. A. (2003). Comparative Study of Trace Element Levels in Some Local Vegetable Varieties and Irrigation Waters from Different Locations in Ilorin, Nigeria. Bulletin of Chemical Society of Ethiopia 17(1):1-6.

[13] Dubey, R.C. and Maheshwari, D.K. (2004). Practical Microbiology. S. Chad \& Company, New Delhi. pp 162- 301.

[14] Ekeanyanwu, R., Ogbuniyi, C. A., and Elienajirhevwe, O. F. (2011). Trace metals distribution in fish tissue, bottom sediments and water from Okemeshi river in Delta State, Nigeria. Environ. Res. J., 5: 6-10.

[15] Eniola, K.I.T. (2005). Biodegradability studies on detergent surfactant in effluent usingresident bacteria of detergent-polluted freshwater bodies in Ilorin, Nigeria.Ph.D. Thesis submitted to Department of Microbiology, University of Ilorin, pp: 129.

[16] Erah, P. O., Akujieze, C. N. and Oteze, G. E. (2011). The Quality of Groundwater in Benin City: A baseline study on inorganic chemicals and microbial contaminants of health

[17] Fawole, M.O. and Oso, B.A. (2001). Laboratory Manual of Microbiolog Spectrum Books Limited, Ibadan, Nigeria. pp 71-80.
[18] Figueras, M.J., Borrego,J.J. , Pike, E.B., Robertson, W. and Ashbolt, N. (2000). Sanitary Inspection and Microbiological Water Quality In: Monitoring Bathing Waters - A Practical Guide to the Design and Implementation of Assessments and Monitoring Programmes. Edited by Jamie Bartram and Gareth Rees. WHO. ISBN 0-419-24390-1. pp 1-52.

[19] Gareth, J. (1973). Pollution on Natural Waters. Water Pollution Control Federal Journal 53: (6) 811-816.

[20] Garrity, G.M., Bell, J.A. and Lilburn,T.G. (2004). Bergey's Manual of Systemic Bacteriology. Taxonomic Outline of the Prokaryotes. Second Edition.Springer New York, U.S.A.

[21] Gupta, s.d., Lee, B., Camacaris, J., and Wu, H.C. (1995). Identification of cut $\mathrm{C}$ and cut $\mathrm{F}$ (nipE) genes involved in copper tolerance in Escherichia coll. Journal of Bacteriology, 1779(15): 4207-4215.

[22] Ishii, S., Ksoll, W. B., Hicks, R. E. and Sadowsky, M.J. (2006). Presence and Growth of Naturalized Escherichia coli in Temperate Soils from Lake Superior Watersheds. Applied and Environmental Microbiology 72(1): 612-621.

[23] Junk, W.J (2002). Long-term environmental trends and the future of tropical wetlands. Environmental Conservation, 294.

[24] Linnik, P.M and Zubenko, I.B. (2000). Role of bottom sediments in the secondary Pollution of aquatic environments by heavy metal compounds. Lakes and Reservoirs Res. Manage. 5(1): 11-21

[25] Maiti SK (2004). Handbook of Methods in Environmental Studies, Water and Waste Water Analysis, Vol. 1, Jaipur: ABD Publishers.

[26] Malik, N., Biswas, A.K., Qureshi T.A., Borana K and Virha R. (2010). Bioaccumulation of heavy metals in fish tissues of a freshwater lake of Bhopal. Environ Monit. Assess. 160: 267-267.

[27] Moore P.D., Jr. Daniel T.C., Gilmour J.T., Shereve B.R., Edward D.R., and Wood, B.H. (1998) "Decreasing Metal Runoff from Poultry Litter with Aluminium Sulfate”. J. Env. Qual. 27, pp.92-99.

[28] Muller, B.A. (2001) : Residential Water Source and the Risk of Childhood Brain Tumors. Env. Health. Perspt. Vol. 109 (6).

[29] Norusis, M. (2006). SPSS 14.0 Guide to Data Analysis. Prentice Hall; software edition.

[30] Odeyemi, A. T., David, O. M., Akinjogunola, O. J., and Oluyege, A.O. (2009). Antibiogram of Enterococcus species Isolated from well water in Iworoko Ekiti, Ekiti State. Nigerian Journal of Microbiology 23(1): 1803-1808. 
[31] Ogbonna, C. E., Njoku, H. O., Onyeagba, R. A. and Nwaugo, V. O. (2010). Effects of seepage from drilling burrow pit wastes on Orashi River, Egbema, Rivers State- Nigeria. Nigerian Journal of Microbiology 24(1): 193-2000.

[32] Ogunnusi, T. A. and Olanipekun, O.A. (2010). Isolation of microorganisms from different water samples consumed in Oyo town, Nigeria. Book of Abstract (NSM FUTO 2010). pp. 37.

[33] Olaitan, S. O. and Lombin, C. (1984). Introduction to Tropical Soil Science. Editor ; Onazi, O. C. Macmillian Publisher Ltd, London pp 18-19.

[34] Olayemi, A.B. (1990). Some Microbiological Aspects of Pollution of Asa River, Ilorin, Nigeria. Ph.D. Thesis (University of Ilorin, Ilorin, Nigeria).

[35] Onions, A.H.S., Allsopp, D., Eggins, H.O.W. (1981). Smith's Introduction to Industrial Mycology. Seventh Edition. Edward Arnold, London.pp 398.

[36] Raveral, O., Cenci, R., Beone, G. M., Dantas, M. and Lodigiani, P. (2003). Trace element concentrations in freshwater mussels and macrophytesas related to those in their environment. Journal of Limnology 62(1): 6170.

[37] Robert, E. R. and Stanley, M. A. (2000). Microbial Sediments. Second Edition. McGraw-Hill, New York. pp 65-87.

[38] Saravanakumar, A., Rajkumar, M., Sesh, J., and Thivakaran, G. A. (2008). Seasonal variations in physic-chemical characteristics of water, sediment and soil texture in arid zone mangrove of KachchhGujarat. J. Environ. Biol., 29: 725-732.

[39] Tamaki, H. , Sekiguchi, Y., Hanada, S. , Nakamura, K.Nomura, N. ,Matsumura, M. and Kamagata, Y. (2005). Comparative analysis of Bacterial Diversity in Freshwater Sediment of a Shallow Eutrophic Lake by Molecular and Improved Cultivation-Based Techniques. Applied Environmental Microbiology 71(4): 2162-2169.

[40] Tukura, B. W., Kabgu, J. A., and Gimba, C. E. (2005). Bioaccumulation of trace metals in fish from Ahmadu Bello University Dam, Zaria, Nigeria. Niger. J. Sci. Res., 5: 91-95.

[41] Vutukuru, S.S (2005). Acute effects of Hexavalent chromium on survival, oxygen consumption hematological parameters and some biochemical profiles of the India Major carp, labeo rohita. International Journal of Environmental Research and Public Health, 2(3), pp. 456-462. 